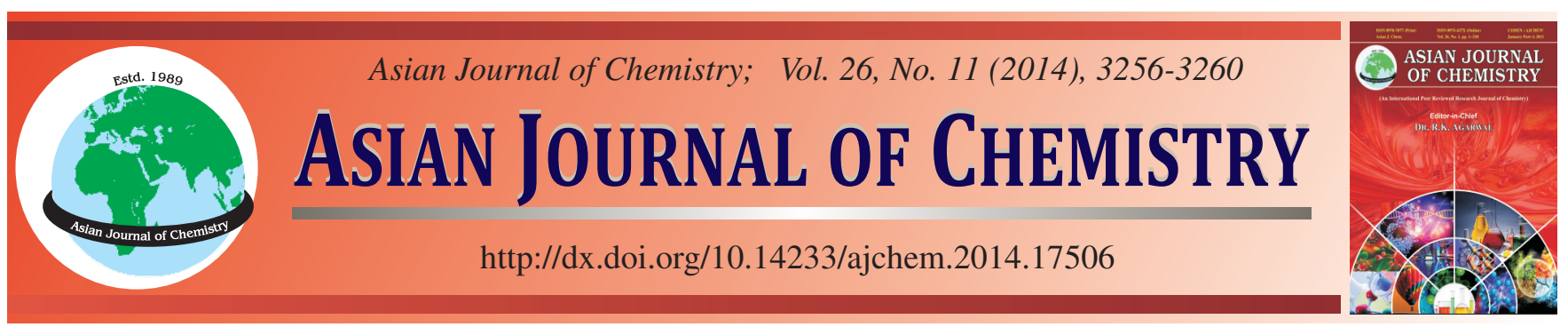

\title{
Effects of Modified Atmosphere Packaging with Chitosan to the Microbial Diversity Change of Cutlassfish (Trichiurus haumela) During Chilled Storage
}

\author{
Wei-Qing Lan, Jing XIE*, JiA-Hui Wu and JiAn Li
}

College of Food Science and Technology, Shanghai Ocean University, Shanghai Engineering Research Center of Aquatic Product Processing and Preservation, Shanghai 201306, P.R. China

*Corresponding author: Fax: +86 21 61900063; Tel: +86 21 61900061; E-mail: jxie@ shou.edu.cn

\begin{abstract}
The microbial diversity changes of cutlassfish (Trichiurus haumela) coated with chitosan in modified atmosphere packaging $\left(50 \% \mathrm{CO}_{2}\right.$ $+20 \% \mathrm{O}_{2}+30 \% \mathrm{~N}_{2}$ ) environment during chilled storage $\left(4 \pm 1{ }^{\circ} \mathrm{C}\right)$ were investigated in this paper. The sensory evaluation, $\mathrm{pH}$ value and total viable counts (TVC) were measured in day $0,2,4,6,8,10,12$. The strains of samples from different days were separated, purified, DNA extraction and PCR amplification. The results showed that samples coated with $10 \mathrm{~g} / \mathrm{L}$ chitosan in modified atmosphere packaging environments could be kept in good qualities significantly and inhibited the growth of microorganism. The shelf-life of cutlassfish was prolonged for almost 8-9 days. At the end of spoilage period, the main change of bacteria in control sample (10d) was Pseudomonas fragi $29.5 \%$, Pseudomonas.fluorescens $33.4 \%$, Shewanella putrefaciens $32.0 \%$, Staphylococcus sciuri $5.1 \%$. The bacteria of sample (12d) with chitosan in modified atmosphere packaging were Pseudomonas fragi $98.8 \%$ and Shewanella putrefaciens $1.2 \%$. Chitosan in modified atmosphere packaging could inhibit the growth of specific spoilage organism (SSO), the dominant species in controlled were Pseudomonas fragi, Pseudomonas fluorescens and Shewanella putrefaciens.
\end{abstract}

Keywords: Trichiurus haumela, Chitosan, Modified atmosphere packaging, Microbial diversity, Chilled storage.

\section{INTRODUCTION}

Cutlassfish (Trichiurus haumela) is an important commercial fish species distributed widely in the East Sea, Yellow Sea, Indian Ocean, West Pacific Sea and one of the fourth major economic fish species in China, which is favored by consumers for its delicious taste and high values of nutrition ${ }^{1}$. The contents of unsaturated fatty acid in cutlassfish were higher than other fishes, which had good protection effects on the cardiovascular system. Cutlassfish plays a certain proportion of fisheries in the east sea due to its fast growth rate.

Aquatic products in circulation were susceptible to be contaminated by bio-chemical and microbial activities for its high water content and abundance of essential nutrients during cold storage ${ }^{2,3}$, researchers show that bacterial activity is the main reason that causes the fish spoilage ${ }^{4}$. The population of bacteria will continue to be changed during chilled storage; some bacteria began to adapt the storage environments and occupy to be the predominant position gradually ${ }^{5}$. It is important to know the change of bacterial quantity and understand the bacterial species in cold storage.
In the last decades, many scientists have carried out the partial researches on the bacteria of spoilage fish species during chilled storage by culture-dependent methods ${ }^{6,7}$, but the research of microbial diversity have been restricted on the cultivable microbial, the composition of bacterial flora in fish and the development of the spoilage flora under different storage conditions was traditionally studied on the basis of cultivation, isolation and identification by phenotypic means ${ }^{8}$. Traditional culturing methods are time-consuming, costly and cannot reflect the actual situation ${ }^{9,10}$. Therefore, culture independent combined with molecular methods have become a very important tool in the study of microbial communities because they are believed to overcome the problem associated with selective cultivation and isolation of bacteria from natural samples.

Modified atmosphere packaging (MAP) could slow the speed of spoilage not by changing the characteristic of products but by adjusting its environment. Modified atmosphere packaging could improve the quality of products and reduce the cost of distribution, thus enhance the flavors and nutrition value ${ }^{11}$. Chitosan is a versatile biopolymer and have abroad range of applications in food industry ${ }^{12}$. It exhibits the antimicrobial 
activity against a range of food-borne microorganisms and has attracted the attention as a potential natural food preservative consequently ${ }^{13,14}$.

Nowadays, MAP with active compounds has proved to be an effective preservative method for the shelf-life extension of fish products ${ }^{15}$. To our best of knowledge, there are no reports of using culture-independent with molecular methods to compare the predominant bacterial composition and diversity in cutlassfish with chitosan in MAP environment. The aim of this work was to explain the shelf-life and quality of cutlassfish used by MAP with chitosan under the cold storage by means of culture-independent and molecular methods.

\section{EXPERIMENTAL}

Sampling: Fresh cutlassfish samples, with a mean weight varying from 200-250 g were obtained directly from a fish market (Luchao Harbor, Shanghai, China). Samples were transferred in ice to Shanghai Engineering Research Center of Aquatic Product Processing and Preservation (Shanghai Ocean University) immediately.

Chitosan: Chitosan (Sinopharm Chemical Reagent Co. Ltd., Beijing, China) was in powder form and moisture contents were less than $6 \%$ it had a deacetylation more than $90.0 \%$. Chitosan was dissolved in sterile water with $1.0 \%$ (v/v) acetic acid and the final concentrations were $10 \mathrm{~g} / \mathrm{L}$.

Preparation of cutlassfish samples: After being gutted, washed, filleted and trimmed in a water-ice mixture, the samples had a weight about $100 \mathrm{~g}$ (15 cm in length and $10 \mathrm{~cm}$ in width) and then be randomly divided into 2 groups. Control samples were individually placed in a sterile plastic bag under atmospheric conditions (Group I), another samples were coated with $10 \mathrm{~g} / \mathrm{L}$ chitosan and packed in vacuum-packaging machine with ratio were for $50 \% \mathrm{CO}_{2}+20 \% \mathrm{O}_{2}+30 \% \mathrm{~N}_{2}$ (Group II). All samples were stored in a chilled room $\left(4 \pm 1{ }^{\circ} \mathrm{C}\right)$ and the initial gas/product ratio was 3:1 in all packages.

Sensory evaluation: Sensory scores of fish sample were calculated using the quality index method (QIM) by five members trained panelists from the laboratory staff (two females and three males between 22 and 36 years old). The QIM is based on the freshness quality grading system ${ }^{16}$. Each assessor scored for colour, texture, odor and appearance from 1 to a maximum of 10 , where 10 represented the freshest quality and the scores increased according to spoilage up to 3 for each parameter. Scores of separate characteristics were summed to give a comprehensive sensory evaluation. Panelists were asked to describe whether the fish samples were acceptable or not. This was used to determine the shelf-life of samples.

pH value: The $\mathrm{pH}$ values were determined to analyze the hygienic standard of fish and other aquatic products according to the GB/T of Chinese standard (GB/T 5009.45-2003). $10 \mathrm{~g}$ sample of fish muscle was mixed with $90 \mathrm{~mL}$ of boiled distilled water and the mixture was filtered $0.5 \mathrm{~h}$ later, the $\mathrm{pH}$ value of filtrate was measured using Sartorius PB-10 pH meter (Sartorius Scientific Instruments Co., Ltd, Germany).

Microbiological analyses: Fish samples were taken aseptically in a vertical laminar-flow cabinet and $25 \mathrm{~g}$ were transferred to a stomacher bag. $225 \mathrm{~mL}$ of $0.1 \%$ peptone water with salt $(\mathrm{NaCl}, 0.85 \%$, w/v) were added and homogenized for $60 \mathrm{~s}$ with a stomacher. From this dilution, other decimal dilutions were obtained and $1 \mathrm{~mL}$ of three dilutions was transferred in triplicate to Petri dishes containing $15 \mathrm{~mL}$ commercial plate count agar (Land-Bridge Technology Co., Ltd, Beijing, China). Total viable counts (TVC) were determined by counting the number of colony-forming units after incubation at $30{ }^{\circ} \mathrm{C}$ for $72 \mathrm{~h}(\mathrm{~GB} / \mathrm{T} 4789.2-2010)$.

Enumeration and isolation of microorganisms: The means and standard deviation were calculated after plate count. Different forms of single bacteria colonial were obtained by culture-dependent method and the bacteria were classified and calculated according to its appearance. All isolated units were examined by gram and spore staining in order to classify the bacterial species. The number of different periods with the same kind of colonies was calculated and selected different kinds of 50 typical single colonies from the plate that contained the amount of 30-300 colonies randomly.

DNA extraction: Pure strains were inoculated in Tryptone Soya Broth (TSB, Shanghai Municipal Center for Disease Control and prevention, China). Then shake at $170 \mathrm{rpm}$ for 17 $\mathrm{h}$ at $37^{\circ} \mathrm{C}$, which were subjected to DNA extraction using Biospin Bacteria Genomic DNA Extraction Kit (Bioer Technology Co., Ltd., Hangzhou, China) according to the manufacturers' instruction.

DNA amplification by PCR and analysis: Universal primer for the domain bacteria were used for amplification on 16S rRNA genes.

PCR products were examined and verified by $1 \%$ agarose gel, PCR amplification products were be electrophoresis about $1500 \mathrm{bp}$. which were purified by DNA purification kit (Tiangen Biotech Co., Ltd., Beijing, China), then sent to determine their sequences. The results of their sequence was compared with the nucleic acid sequence alignment from GenBank that had higher similar sequences to NCBI (http://www.ncbi.nlm.nih.gov/blast/) and Chromas version1.62 and DNAMAN (version 6.0) were used for multiple comparison phylogenetic tree construction. The reaction system and reaction condition of PCR amplification are given in Tables 1 and 2.

\begin{tabular}{|c|c|c|}
\hline \multicolumn{3}{|c|}{$\begin{array}{c}\text { TABLE-1 } \\
\text { REACTION SYSTEM OF PCR AMPLIFICATION }\end{array}$} \\
\hline Reaction component of PCR & Volume $(\mu \mathrm{L})$ & Time (min) \\
\hline $2 \times$ Taq PCR master mix & 12.5 & 5 \\
\hline Forward primer: $27 \mathrm{f}$ & 1.0 & 5 \\
\hline Reverse primer: $1492 \mathrm{r}$ & 1.0 & 5 \\
\hline Template DNA & 1.0 & 1 \\
\hline $\mathrm{ddH}_{2} \mathrm{O}$ & 9.5 & 2 \\
\hline Total & 25.0 & 10 \\
\hline
\end{tabular}

\begin{tabular}{cccc}
\multicolumn{4}{c}{ TABLE-2 } \\
\multicolumn{4}{c}{ REACTION CONDITION OF PCR AMPLIFICATION } \\
\hline No. & Reaction temp. $\left({ }^{\circ} \mathrm{C}\right)$ & Reaction & Time $(\mathrm{min})$ \\
\hline $\mathrm{a}$ & 94 & Amplification & 5 \\
$\mathrm{~b}$ & 94 & Pre-degeneration & 5 \\
$\mathrm{c}$ & 94 & Degeneration & 1 \\
$\mathrm{~d}$ & 57 & Annealing & 1 \\
$\mathrm{e}$ & 72 & Complexion & 2 \\
$\mathrm{f}$ & 72 & Extension & 10 \\
\hline Note: Repeat $\mathrm{c}, \mathrm{d}, \mathrm{e}$ for 25 times. &
\end{tabular}


Physiological and biochemical analysis: Pure strains were classified by physiological and biochemical identification, such as $\mathrm{H}_{2} \mathrm{~S}$, fermentation of sugar and alcohol experiments.

Statistical analysis: Samples were examined at $48 \mathrm{~h}$ intervals for sensory assessment, chemical and TVC analysis. Experiments were replicated twice. Measurements were run in triplicate for each replicate $(n=2 \times 3)$. Results were reported as mean values \pm standard deviation. The student's $t$-test was employed to find out the significance between different treatments and storage time. Data are expressed as mean values $(\mathrm{n}=3)$ accompanied by standard error of means.

Analyses were performed with the SPSS software (version 13.0) (SPSS, Chicago, IL, USA). Descriptive statistics (mean, standard deviation and coefficient of variation), one-way ANOVA, multiple comparison with the Turkey test, linear regression analysis and factorial analysis were applied. Significance level was set at 0.05 . The figures are drawn as Origin software (Version Pro V8.5).

\section{RESULTS AND DISCUSSION}

Sensory analyses: The results of sensory evaluation in samples are presented in Fig. 1. Samples with the characteristic of fresh fish had a pleasant taste and odor on day 0 . The scores showed a similar pattern of increasing unacceptability. The shelf life of samples was day 4 for group I and day 12 for group II. It is well known that fish spoilage gives rise to the subsequent development of strongly fishy, rancid and putrid odors.

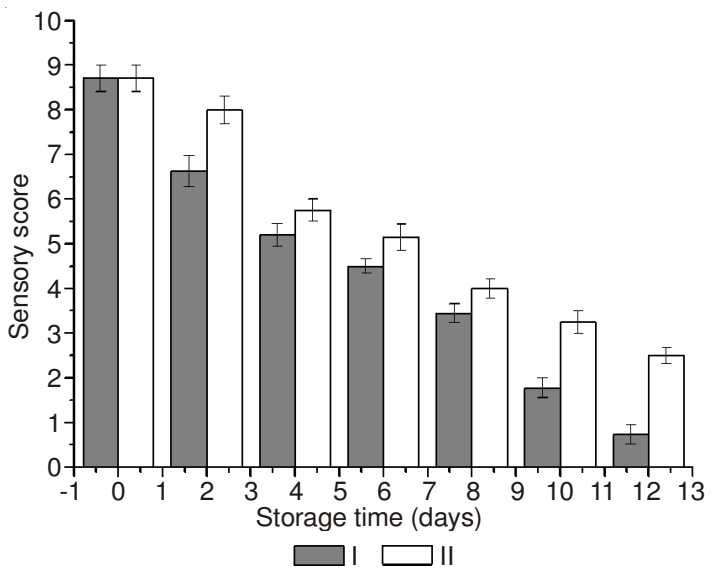

Fig. 1. Changes in sensory score of T. haumela during chilled storage

pH value: Changes in $\mathrm{pH}$ values during storage were shown in Fig. 2. The initial $\mathrm{pH}$ of the fish samples was 7.020 \pm 0.012 . Differences in the initial values of $\mathrm{pH}$ may be due to the species, diet, seasons and the level of activity or stress during the catch as well as the type of muscle. pH values of group I decreased in early stages and then increased gradually. The initial decrease of $\mathrm{pH}$ might be related to the accumulation of lactic acid, a product of glycolysis, while the increase in late storage may be caused by the growth of spoilage bacteria leading to the accumulation of alkaline components, such as ammonia and tri-methylamine. The results reflected that $\mathrm{pH}$ values of different groups increased after values reached the minimum on day 4, especially group I increased much faster because glycolysis reaction caused by the stop in circulation of blood and produced large amounts of lactic acid, succinic acid,

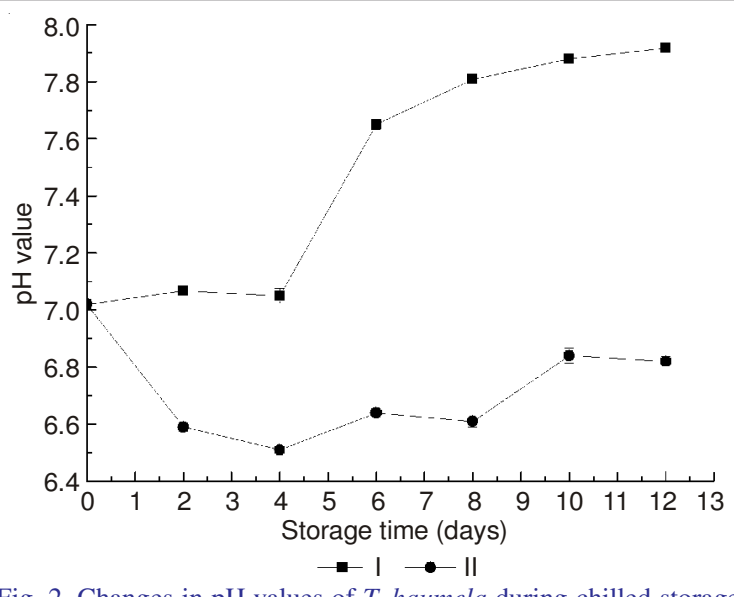

Fig. 2. Changes in $\mathrm{pH}$ values of T. haumela during chilled storage

phosphoric acid, which led to the enhancement of organism acid and the decrease of $\mathrm{pH}$ value. Along with the extension of storage time, protein decomposition produced amine and other alkali substances, because the increase of microorganisms and enzyme activity led to the gradual increase of $\mathrm{pH}$ value. Group II could inhibit the increase of microorganisms, enzyme activity and slow down the speed of $\mathrm{pH}$ value.

Total viable counts: Because microbial activity is mainly responsible for spoilage of lightly preserved seafood, total viable counts (TVC) is an indicator parameter of product degradation, which in fish is mostly due to the growth of $\mathrm{SSO}^{17}$. It can dictate the sensory rejection of products, even when TVC is lower than the normal limits of acceptability ${ }^{18}$, which has been used in mandatory seafood standards in many countries. Total viable counts change of sample during chilled storage were shown in Fig. 3.

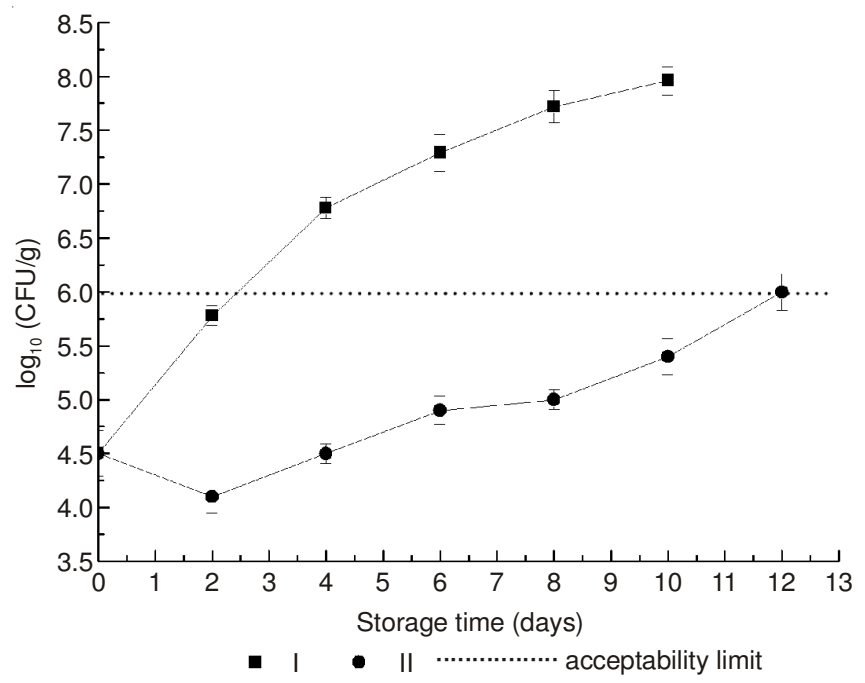

Fig. 3. Changes in TVC of T.haumela during chilled storage

Total viable counts of group I was significantly increased beyond the limit of standard $(6.0 \log (\mathrm{CFU} / \mathrm{g}))$ on day 4 during chilled storage. The growth rate of TVC in group II was evidently slower than group I. This indicated that group II could inhibit the increase of microorganism effectively. The higher concentration of $\mathrm{CO}_{2}$, the better inhibition effects on bacteria. Group II could inhibit or reduce the growth of various aerobic spoilage bacteria and provide the conditions for the 
growth of gram-positive bacteria ${ }^{19}$. When compared to group I, the effect of group II could inhibit the microorganism significantly and not beyond the limit of standard on day 12 .

Properties of bacterial colony: The stains were separated into 10 kinds of typical bacteria at different storage time by comparing and classifying repeatedly, which were named as $\mathrm{X}_{1}, \mathrm{X}_{2} \ldots \mathrm{X}_{10}$, respectively. The prosperities of bacteria on T. haumela during chilled storage is presented in Table- 3 .

DNA amplification and analysis by PCR: The DNA of unknown strains was extracted and amplified by PCR at $16 \mathrm{~S}$ regions, the results of electrophoresis were shown in Figs. 4 and 5.

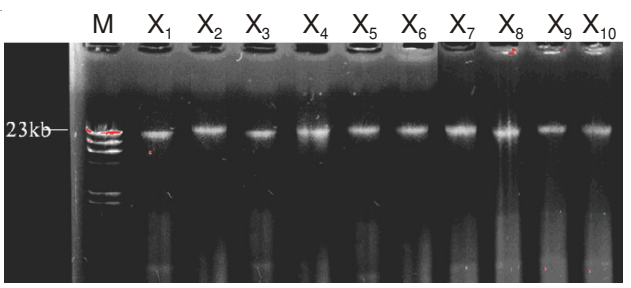

Fig. 4. Electrophoretic analysis of DNA from 10 samples

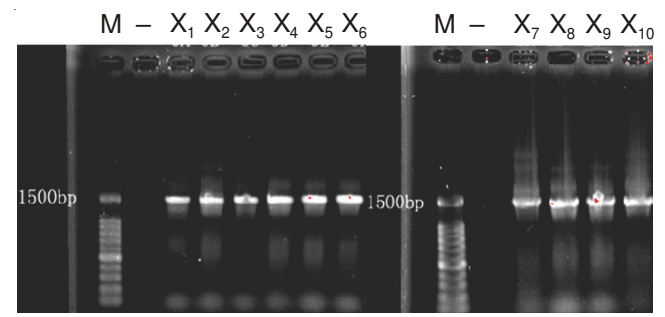

Fig. 5. Electrophoretic analysis of PCR amplification products of the $16 \mathrm{~S}$ rRNA gene fragments from 10 samples (Note: "-" are negative control)

The sequences of 10 strains were presented at NCBI and get the temporary registration number in the GenBank database. 8 strains from the published 16Sr RNA sequence at the GenBank were selected and compared by BLAST software, respectively, which had the homology more than $99 \%$. The relationship of bacterial species was obtained by phylogenetic tree.

Physiological and biochemical analysis: From the statistics of bacteria, the main bacterial were $\mathrm{X}_{1}, \mathrm{X}_{2} \ldots \mathrm{X}_{10}$ during chilled storage. The results of physiological and biochemical test were given in Table-4.

From the results of phylogenetic tree, physiological and biochemical tests, it can prove that $\mathrm{X}_{1}, \mathrm{X}_{2} \ldots \mathrm{X}_{10}$ belong to Pseudomonas fluorescens, Shewanella putrefaciens, Chryseobacterium indoltheticum, Psychrobacter spp., Staphylococcus saprophyticus, Staphylococcus sciuri, Aerococcus viridans, Brochothrix thermosphacta, Kocuria spp., respectively. The effects of group II on the proportion of bacteria changes and composition of cutlassfish at different storage time during chilled storage could be obtained (Table-5).

\section{Conclusion}

The results showed that samples coated with $10 \mathrm{~g} / \mathrm{L}$ chitosan in MAP environment could be kept in good qualities significantly and inhibited the growth of microorganism. The shelf-life of cutlassfish was prolonged for almost 8-9 days. At the end of spoilage period, the main changes of bacteria in group I (10 d) were Pseudomonas fragi $29.5 \%$, Pseudomonas fluorescens $33.4 \%$, Shewanella putrefaciens $32.0 \%$, Staphylococcus sciuri $5.1 \%$ and group II (12d) were Pseudomonas fragi $98.8 \%$, Shewanella putrefaciens $1.2 \%$. From the result of PCR and microbiological method, it was showed that there were mainly 10 typical bacterial strains of cutlassfish during chilled storage. The dominant species were Pseudomonas fluorescens, Pseudomonas fragi and Shewanella putrefaciens. Group II could inhibit the growth of Pseudomonas fluorescens, Shewanella putrefaciens, Chryseobacterium indoltheticum, Psychrobacter spp., Staphylococcus saprophyticus, Staphylococcus sciuri, Aerococcus viridans, Brochothrix thermosphacta and Kocuria spp. Gill ${ }^{20}$ found that Pseudomonas spp. and Shewanella spp. were the SSO in cold-chain circulation, which could cause the colour change of fish and due to its deterioration finally.

\begin{tabular}{|c|c|c|c|c|c|c|c|c|c|c|}
\hline \multicolumn{11}{|c|}{$\begin{array}{c}\text { TABLE-3 } \\
\text { TIES OF BACTERIA ON } 7\end{array}$} \\
\hline Stains No. & $\mathrm{X}_{2}$ & $\mathrm{X}_{2}$ & $\mathrm{X}_{3}$ & $\mathrm{X}_{4}$ & $\mathrm{X}_{5}$ & $\mathrm{X}_{6}$ & $\mathrm{X}_{7}$ & $\mathrm{X}_{8}$ & $\mathrm{X}_{9}$ & $\mathrm{X}_{10}$ \\
\hline Gram staining & $\mathrm{G}^{-}$ & $\mathrm{G}^{-}$ & $\mathrm{G}^{-}$ & $\mathrm{G}^{-}$ & $\mathrm{G}^{-}$ & $\mathrm{G}^{-}$ & $\mathrm{G}^{-}$ & $\mathrm{G}^{-}$ & $\mathrm{G}^{-}$ & $\mathrm{G}^{-}$ \\
\hline Shape & Rhabditiform & Bhabditiform & Rhabditiform & Rhabditiform & Rhabditiform & Spherical & Spherical & Annular & Rhabditiform & Spherical \\
\hline $\begin{array}{l}\text { Bacterial } \\
\text { morphology }\end{array}$ & & 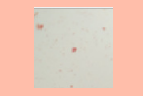 & & t. & $\begin{array}{r}x y \\
y=8 \\
y=2\end{array}$ & & $=\frac{5}{-1}+4$ & Sivi... & & $\cdots$ \\
\hline $\begin{array}{l}\text { Colonical } \\
\text { color }\end{array}$ & Yellow & Light & Light brown & Orange & Light & $\begin{array}{l}\text { Light } \\
\text { yellow }\end{array}$ & White & $\begin{array}{l}\text { Light } \\
\text { yellow }\end{array}$ & Light brown & $\begin{array}{l}\text { Light } \\
\text { yellow }\end{array}$ \\
\hline $\begin{array}{l}\text { Colonial } \\
\text { degree of } \\
\text { uplift }\end{array}$ & Convex & Convex & Convex & Convex & Convex & Convex & Convex & Convex & Convex & Convex \\
\hline $\begin{array}{c}\text { Colonial } \\
\text { surface state }\end{array}$ & Smooth & Smooth & Smooth & Smooth & Smooth & Smooth & Smooth & Smooth & Smooth & Smooth \\
\hline Colonial luster & Glossy & Glossy & Glossy & Glossy & Glossy & Glossy & Glossy & Glossy & Glossy & Glossy \\
\hline $\begin{array}{l}\text { Colonial } \\
\text { degree of wet } \\
\text { and dry }\end{array}$ & Moist & Moist & Moist & Moist & Moist & Moist & Moist & Moist & Moist & Moist \\
\hline $\begin{array}{c}\text { Colonial } \\
\text { degree of } \\
\text { transparency }\end{array}$ & Translucent & Translucent & Opaque & Translucent & Opaque & Translucent & Translucent & Translucent & Opaque & Opaque \\
\hline
\end{tabular}


TABLE-4

PHYSIOLOGICAL AND BIOLOGICAL TEST OF MICROBIAL IN T. haumela

\begin{tabular}{ccccccccccc}
\hline Strains No. & $\mathrm{X}_{1}$ & $\mathrm{X}_{2}$ & $\mathrm{X}_{3}$ & $\mathrm{X}_{4}$ & $\mathrm{X}_{5}$ & $\mathrm{X}_{6}$ & $\mathrm{X}_{7}$ & $\mathrm{X}_{8}$ & $\mathrm{X}_{9}$ & $\mathrm{X}_{10}$ \\
\hline Raffinose & - & - & - & - & - & - & - & - & - & - \\
Starch & + & - & - & - & - & - & - & - & - & - \\
Arginine & - & - & - & - & - & - & - & - & - & - \\
Arabinose & - & - & - & - & - & - & - & - & - & - \\
Cellobiose & - & - & - & - & - & - & - & + & - & - \\
Fructose & - & - & - & - & - & + & + & + & - & - \\
Galactose & - & - & - & - & - & - & - & + & - & - \\
Rhamnose & - & - & - & - & - & - & - & - & - & - \\
N-Acetyl glucosamine & - & - & - & NT & - & - & - & NT & NT & - \\
Melibiose & - & - & - & NT & - & - & - & NT & NT & - \\
Xylitol & - & - & - & NT & - & - & - & NT & NT & - \\
H S & - & - & + & NT & - & + & - & NT & NT & - \\
Melezitose & - & - & - & NT & - & - & - & NT & NT & - \\
D-nucleotide & - & - & - & NT & - & - & - & NT & NT & - \\
Malonate & - & - & NT & NT & - & - & NT & NT & NT & NT \\
Carbamide & + & NT & - & NT & + & - & NT & NT & NT & NT \\
\hline Note: +: Most are $(\geq 90 \%)$ positive; & - Most are $(\geq 90 \%)$ negative; NT: No test. & &
\end{tabular}

\section{TABLE-5}

EFFECTS ON THE PROPORTION OF BACTERIA CHANGES AND COMPOSITION OF T. haumela FROM DIFFERENT METHODS DURING CHILLED STORAGE

\begin{tabular}{|c|c|c|c|c|c|c|c|c|c|c|c|c|}
\hline \multirow{2}{*}{ Strains No. } & \multirow{2}{*}{$\frac{0 \text { day }}{\mathrm{I}}$} & \multicolumn{2}{|c|}{2 days } & \multicolumn{2}{|c|}{4 days } & \multicolumn{2}{|c|}{6 days } & \multicolumn{2}{|c|}{8 days } & \multicolumn{2}{|c|}{10 days } & \multirow{2}{*}{$\frac{12 \text { days }}{\text { II }}$} \\
\hline & & I & II & I & II & I & II & I & II & I & II & \\
\hline $\mathrm{G}^{-}$ & 9.4 & 39.1 & 100 & 13.3 & 97.7 & 87.3 & 97.7 & 73.5 & 100 & 9.49 & 100 & 100 \\
\hline $\mathrm{X}_{1}$ Pseudomonas fragi & 0 & 1.3 & 93.4 & 0 & 83.8 & 14.7 & 69.8 & 3 & 64.4 & 29.5 & 80 & 98.8 \\
\hline $\mathrm{X}_{2}$ Pseudomonas fluorescens & 0 & 5.3 & 0 & 0 & 0 & 24.6 & 0 & 35 & 0 & 33.4 & 0 & 0 \\
\hline $\mathrm{X}_{3}$ Shewanella putrefaciens & 0 & 0 & 6.6 & 0 & 8.1 & 48 & 27.9 & 35.5 & 35.6 & 32 & 20 & 1.2 \\
\hline $\mathrm{X}_{4}$ Chryseobacterium indohhetricum & 6.3 & 342.5 & 0 & 0 & 5.8 & 0 & 0 & 0 & 0 & 0 & 0 & 0 \\
\hline $\mathrm{X}_{5}$ Psychrobacter spp. & 3.1 & 0 & 0 & 13.3 & 0 & 0 & 0 & 0 & 0 & 0 & 0 & 0 \\
\hline $\mathrm{G}^{+}$ & 90.6 & 60.9 & 0 & 86.7 & 2.3 & 12.7 & 2.3 & 26.5 & 0 & 5.1 & 0 & 0 \\
\hline $\mathrm{X}_{6}$ Staphylococcus saprophyticus & 41.5 & 1.3 & 0 & 57.8 & 0 & 0 & 0 & 15.2 & 0 & 0 & 0 & 0 \\
\hline $\mathrm{X}_{7}$ Staphylococcus sciuri & 17.8 & 56.9 & 0 & 28.9 & 0 & 10 & 0 & 11.3 & 0 & 5.1 & 0 & 0 \\
\hline $\mathrm{X}_{8}$ Aerococcus viridans & 0 & 2.7 & 0 & 0 & 0 & 0 & 0 & 0 & 0 & 0 & 0 & 0 \\
\hline $\mathrm{X}_{9}$ Brochlothrix thennosphacta & 0 & 0 & 0 & 0 & 0 & 2.7 & 0 & 0 & 0 & 0 & 0 & 0 \\
\hline $\mathrm{X}_{10}$ Kocuria Spp. & 31.3 & 0 & 0 & 0 & 2.3 & 0 & 2.3 & 0 & 0 & 0 & 0 & 0 \\
\hline
\end{tabular}

\section{ACKNOWLEDGEMENTS}

The study was supported by the 'twelve five' national support planning projects (2013BAD19B06), Shanghai Agricultural Science and Technology Research 2013, No. 3-4 and Shanghai Engineering Research Center of Aquatic-Product Processing \& Preservation (11DZ2280300).

\section{REFERENCES}

1. J.Z. Bi, C.W. Shao, G.D. Miao, H.Y. Ma and S.L. Chen, Conserv. Genet, 10, 1171 (2009).

2. T.C. Jackson, G.R. Acuff and J.S. Dickson, in eds.: M.P. Doyle and T.J. Beuchat, Meat, Poultry and Seafood, In: Food Microbiology: Fundamentals and Frontiers Washington, D.C: ASM Press, pp. 83-100 (1997).

3. E. Hilario, T.R. Buckley and J.M. Young, Antonie van Leeuwenhoek, 86, 51 (2004).

4. M. Gennari, S. Tomaselli and V. Cotrona, Food Microbiol., 16, 15 (1999).

5. P.S. Taoukis, K. Koutsoumanis and G.J.E. Nychas, Int. J. Food Microbiol., 53, 21 (1999).

6. L. Gram and H.H. Huss, Int. J. Food Microbiol., 33, 121 (1996).
7. N.C. Gillespie and I.C. Macrae, J. Appl. Bacteriol., 39, 91 (1975).

8. Y. Blixt and E. Borch, Meat Sci., 60, 371 (2002).

9. R.I. Amann, W. Ludwig and K.H. Schlefer, Microbiol. Rev., 59, 143 (1995).

10. N.R. Pace, Science, 276, 734 (1997).

11. B. Ooraikul and M.E. Stiles, Modified Atmosphere Packaging of Food, Ellis Horwood, England (1991).

12. R.N. Tharanathan and F.S. Kittur, Crit. Rev. Food Sci. Nutr., 43, 61 (2003).

13. C.-S. Chen, W.-Y. Lian and G.-J. Tsai, J. Food Prot., 61, 1124 (1998).

14. F. Shahidi, J.K.V. Arachchi and Y.J. Jeon, Trends Food Sci. Technol., 10, 37 (1999).

15. M. Mastromatteo, A. Conte and M.A. Del Nobile, Food Eng. Rev., 2, 28 (2010).

16. Y. Yokoyama, M. Sakaguchi, F. Kawai and M. Kanamori, Nippon Suisan Gakkai Shi, 58, 2125 (1992).

17. P. Dalgaard, Int. J. Food Microbiol., 26, 319 (1995).

18. B.M. Poli, A. Messini, G. Parisi, F. Scappini, V. Vigiani, G. Giorgi and M. Vincenzini, Int. J. Food Sci. Technol., 41, 444 (2006).

19. C. Ruiz-Capillas, A. Saavedra and A. Moral, Eur. Food Res. Technol., 218, 7 (2003)

20. C.O. Gill, Meat Sci., 43, 99 (1996). 